\title{
Essays on informal versus formal economy choices
}

Citation for published version (APA):

Balde, R. (2021). Essays on informal versus formal economy choices. [Doctoral Thesis, Maastricht University]. ProefschriftMaken. https://doi.org/10.26481/dis.20210610rb

Document status and date:

Published: 01/01/2021

DOI:

10.26481/dis.20210610rb

Document Version:

Publisher's PDF, also known as Version of record

\section{Please check the document version of this publication:}

- A submitted manuscript is the version of the article upon submission and before peer-review. There can be important differences between the submitted version and the official published version of record.

People interested in the research are advised to contact the author for the final version of the publication, or visit the DOI to the publisher's website.

- The final author version and the galley proof are versions of the publication after peer review.

- The final published version features the final layout of the paper including the volume, issue and page numbers.

Link to publication

\footnotetext{
General rights rights.

- You may freely distribute the URL identifying the publication in the public portal. please follow below link for the End User Agreement:

www.umlib.nl/taverne-license

Take down policy

If you believe that this document breaches copyright please contact us at:

repository@maastrichtuniversity.nl

providing details and we will investigate your claim.
}

Copyright and moral rights for the publications made accessible in the public portal are retained by the authors and/or other copyright owners and it is a condition of accessing publications that users recognise and abide by the legal requirements associated with these

- Users may download and print one copy of any publication from the public portal for the purpose of private study or research.

- You may not further distribute the material or use it for any profit-making activity or commercial gain

If the publication is distributed under the terms of Article $25 \mathrm{fa}$ of the Dutch Copyright Act, indicated by the "Taverne" license above, 


\section{SUMMARY}

The dissertation's main objective is to examine the main determinants of the informal economy to inform policymakers on the best approach to tackle it. The informal economy is largely dominated by vulnerable and poor workers. There is also empirical and anecdotal evidence suggesting that a large informal economy negatively affects formal firms' innovation and creates a loss of resources for governments. Whereas these have led to an enormous amount of policies or reforms aimed at reducing the size of the informal economy, there is no conclusive evidence of their success. Some policies opt for a stricter stance towards informality. While emerging voices advocate for an increase in formalisation advantages. Much of the evidence in the literature is limited to South America or Asia. Sub-Saharan Africa has its specificities, and policies adopted in other regions may not entirely apply and produce similar results. Careful attention needs to be paid to the potential consequences of each approach because most of the population in Sub-Saharan Africa have their livelihoods in the informal economy.

To this end, Chapter 2 focuses on the informal economy's approach that consists of increasing the costs of informality. We particularly evaluate the effects of trading permits in the informal sector and apply a difference-in-difference approach. We use the National Income Dynamics panel dataset in South Africa. The main results provide evidence on the effectiveness of such an approach in reducing informal entrepreneurship but at a cost. The policy has equally increased unemployment and does not increase formal entrepreneurship. A heterogeneous analysis of the impact reveals that those often considered vulnerable, such as women and black individuals, are the most affected.

Chapter 3 investigates the effects of an increase in the benefits of formalisation on firms' tax compliance. More precisely, it studies the effects of a more developed financial sector on value-added tax, profit tax and local tax compliances. The analysis relies on small business survey data covering 12 African economies and adopts a trivariate probit approach. The main results reveal that financial development effectively increases tax compliance. The results highlight that an increase in the advantages of running formal activities successfully increases formalisation. Indeed, lower costs of banks increase the opportunity cost of operating informally. The results also reveal that informal finance may mitigate the effects of financial development on formalisation. 
Chapter 4 investigates whether there is a public rationale for attempting to formalise small firms. It examines whether small firms benefit from formalisation. More specifically, we estimate the effects of formalisation on improved performance, export, trade credit and access to loans from banks. We again use the small business survey data that covers 12 African economies. The results show that formalisation did not improve the performance of firms and that the effects persist for firms of all sizes. Also, firms without employees are more importantly affected than firms with employees. For other outcomes such as export, access to trade credit, and loans from Banks, formalisation has a positive impact. We equally investigate whether business training and tips from incubators can mitigate the adverse effects and enhance the positive ones. The results provide evidence on the effective role of training and advice from incubators in cushioning the adverse effects and enhancing the positive impacts of formalisation for small businesses.

Chapter 5 examines whether an employment tax credit targeted at young people positively impacts formal work. We adopt a difference-in-difference approach to evaluate the impacts of the South-African employment tax incentive introduced in 2014. The data used is the National Income Dynamics panel dataset in South Africa. The results show that the ETI program increased the probability to have jobs and formal employment for the individuals who were previously unemployed or informally employed. We also find that the impact of the program increased over time.

Finally, Chapter 6 concludes the thesis with some policy recommendations, limitations of the research and avenues for future research. 